\title{
Efficiency of inert mineral dusts in the control of corn weevil
}

\author{
Carlos F. Jairoce ${ }^{1}$, Cristiano M. Teixeira' ${ }^{2}$, Adrise M. Nunes², \\ Daniela R. Holdefer ${ }^{3}$, Alexandra P. Krüger ${ }^{4} \&$ Flávio R. M. Garcia ${ }^{5}$
}

${ }^{1}$ Universidade Lurio/Faculdade de Ciências Agrárias/Departamento de Protecção de Plantas. Moçambique. E-mail: jairoce09@gmail.com

${ }^{2}$ Universidade Federal de Pelotas/Instituto de Biologia/Programa de Pós-Graduação em Entomologia. Pelotas, RS. E-mail: crisakst@yahoo.com.br; adrisenunes@gmail.com.br

${ }^{3}$ Universidade Estadual do Paraná/Departamento de Biologia. União da Vitória, PR. E-mail: dwoldan@yahoo.com.br

${ }^{4}$ Universidade Federal de Pelotas/Faculdade de Agronomia Eliseu Maciel/Departamento de Fitossanidade. Pelotas, RS.E-mail: alexandra_kruger@hotmail.com

${ }^{5}$ Universidade Federal de Pelotas/Departamento de Ecologia, Zoologia e Genética/Laboratório de Ecologia de Insetos. Pelotas, RS. E-mail: flaviormg@hotmail.com (Corresponding author)

\section{Key words:}

Sitophilus zeamais alternative control abrasive effect

\begin{abstract}
A B S T R A C T
Corn weevil (Sitophilus zeamais) may cause great losses in the crop and in stored corn grains. This insect is controlled with the use of chemical insecticides, which may cause serious damage to human health. One alternative of control is the use of inert dusts. The objective of this study was to evaluate the efficiency of inert dusts in the control of $S$. zeamais under laboratory conditions. The experiment was conducted in 2014, in a completely randomized design, and the treatments consisted of basalt dust with three different granulometries (A, B and C) and diatomaceous earth, each of which at the doses of 2 and $4 \mathrm{~kg} \mathrm{t}^{-1}$ and a control (no application). Each treatment had four replicates, and the sample unit consisted of $20 \mathrm{~g}$ of corn grains infected with 10 adults of $S$. zeamais kept in temperature-controlled chamber at $25^{\circ} \mathrm{C}, 70 \% \mathrm{RH}$ and photophase of $12 \mathrm{~h}$. The dust efficiency was calculated using the equation of Abbott. The mortality rate was higher with the use of diatomaceous earth, reaching $100 \%$ after 5 days of exposure and the percentage of control for basalt dusts, 29 days after treatment, was above $80 \%$.
\end{abstract}

\section{Palavras-chave:} Sitophilus zeamais controle alternativo efeito abrasivo

\section{Eficiência de pós inertes minerais no controle do gorgulho-do-milho}

\section{R E S U M O}

O gorgulho-do-milho (Sitophilus zeamais) pode causar grande prejuízo na cultura e nos grãos de milho armazenados. O controle deste inseto é efetuado através do uso de inseticidas químicos passíveis de ocasionar sérios problemas à saúde humana; uma alternativa de controle é a utilização de pós inertes. O presente trabalho objetivou avaliar a eficiência de pós inertes no controle de $S$. zeamais em condições de laboratório. $\mathrm{O}$ experimento foi conduzido durante o ano de 2014; os tratamentos, constituídos por pó de basalto em três diferentes granulometrias (A, B e C) e terra de diatomáceas, cada um nas doses de 2 e $4 \mathrm{~kg} \mathrm{t}^{-1}$ e ainda testemunha (sem aplicação), foram realizados em delineamento experimental inteiramente casualizado. Cada tratamento foi constituído de quatro repetições e a unidade amostral composta por $20 \mathrm{~g}$ de grãos de milho infestados com 10 adultos de $S$. zeamais mantidos em câmara climatizada com temperatura de 25 ${ }^{\circ} \mathrm{C}$, UR $70 \%$ e foto-fase de $12 \mathrm{~h}$, pela equação de Abbott foi calculada a eficiência dos pós; a mortalidade foi mais rápida com a terra de diatomácea chegando a $100 \%$ cinco dias após a exposição; a porcentagem de controle com os pós de basalto, 29 dias após os tratamentos, foi superior a $80 \%$. 


\section{INTRODUCTION}

Corn (Zea mays L.) is widely cultivated in small family farms in the state of Rio Grande do Sul, in which the conservation and protection of stored grains constitute an alimentary, social and economic need (Ribeiro et al., 2008).

Corn weevil (Sitophilus zeamais Motschulsky 1885) is the main pest species of stored corn (Ceruti \& Lazzari, 2005), due to its high biotic potential and capacity to attack grains both at field and in deposits and to survive at great depths in the mass of grains, besides being cosmopolitan and requiring a short period to complete its cycle (Faroni, 1992). Furthermore, the primary pest can infest entire grains, favoring the occurrence of secondary pests (Gallo et al., 2002).

The control of $S$. zeamais varies widely between different regions. In general, chemical control has been the most adopted, generally applied preventively using liquid insecticides sprayed on the grains at the entrance of the storing unity (Arthur, 1994; Silva et al., 2007). In already infested grains, the control has been preferentially performed using liquid or solidified fumigants, such as phosphine (Almeida et al., 1999).

Currently, agro-ecological researches search for alternative controls in order to avoid imbalances caused by the inadequate use of chemical products, which lead to the need for rethinking the control tactics used in the integrated pest management, especially when it comes to products ready for consumption (Porto \& Soares, 2012).

The use of inert dusts, a technique used by family farmers before the advent of synthetic insecticides, has reemerged as an important alternative for the control of pest insects in stored grains (Lorini, 1998). According to Subramanyam \& Roesli (2000), inert dusts act physically, through abrasion of the insect's body, which leads to the destruction of the lipid layer that forms the external surface of the cuticle, facilitating the loss of water and, thus, causing its death by dehydration.

Therefore, considering the necessity of using alternative forms of control, this study aimed to evaluate the efficiency of inert dusts in the control of S. zeamais under laboratory conditions.

\section{Material ANd Methods}

The experiment was carried out in 2014, at the Insect Ecology Laboratory of the Federal University of Pelotas, in Pelotas-RS, Brazil. The insects were obtained from the insect rearing of the laboratory and placed on corn grains in $400-\mathrm{mL}$ glass jars with opening of $10 \mathrm{~cm}$ of diameter, involved in the upper part with a voile fabric and fixed with a rubber band.

The treatments consisted of basalt dust with granulometry of $0.1 \mathrm{~mm}(\mathrm{~A}), 0.3 \mathrm{~mm}(\mathrm{~B})$ and $0.5 \mathrm{~mm}(\mathrm{C})$, and diatomaceous earth (INSECTO ${ }^{\circ}$ ), all at the doses of 2 and $4 \mathrm{~kg} \mathrm{t}^{-1}$ of corn grains. The control treatment received no application of the products (Table 1). The experiment was set in a completely randomized design, with nine treatments and four replicates. Each sampling unit consisted of Petri dishes (90 x $15 \mathrm{~mm}$ ) with $20 \mathrm{~g}$ of corn grains, with moisture content of $12 \%$, which were mixed and agitated manually for 2 min along with the inert dusts at the doses of 2 and $4 \mathrm{~kg} \mathrm{t}^{-1}$. Treated corn grains were then infested with 10 unsexed adults of S. zeamais with 10 to
14 days of age, arranged in each replicate and maintained in a BOD (Biochemical oxygen demand) chamber, at temperature of $25 \pm 3^{\circ} \mathrm{C}$, humidity of $70 \pm 10 \%$ and photophase of $12 \mathrm{~h}$. The number of live insects was evaluated from the first to the 29 th day after treatment. The number of live insects in each dish was quantified, and the insects that did not move for $2 \mathrm{~min}$ were considered as dead (Antunes et al., 2013).

The diatomaceous earth used (Figure 1D) was the base of the commercial product INSECTO', from the company Bernardo Química, São Vicente, SP. It is an inert dust registered and recommended for the control of pests in stored grains, composed of silicon dioxide [867 $\mathrm{g} \mathrm{kg}^{-1}\left(86.7 \% \mathrm{~m} \mathrm{~m}^{-1}\right)$ ] and inert ingredients [ $\left.133 \mathrm{~g} \mathrm{~kg}^{-1}\left(13.3 \% \mathrm{~m} \mathrm{~m}^{-1}\right)\right]$.

The basalt dusts used in the experiment differ with respect to granulometry (Figure 1) and were obtained from the company Ekosolos Indústria Remineradora de Solos Ltda., located in the state of Paraná. Ekosolos' basalt dust is a mixture of two finely ground basalt rocks: Microgabbro (Figure 1A) and Basaltic quartz latite (Figure 1B and C) (Table 2). This mixture has granulometry lower than $0.9 \mathrm{~mm}$, forming gradient until 200 mesh.

The insects were evaluated at 5, 9, 13, 17, 21, 25 and 29 days after treatment, through the number of live insects in each

Table 1. Treatments of basalt dust and diatomaceous earth at the doses of 2 and $4 \mathrm{~kg} \mathrm{t}^{-1}$ applied in corn grains

\begin{tabular}{|cc}
\hline \multicolumn{1}{c}{ Treatments } & Doses $\left(\mathbf{k g ~ t}^{-1}\right)$ \\
T1 - Basalt dust A $(0.1 \mathrm{~mm})$ & 2 \\
T2 - Basalt dust A $(0.1 \mathrm{~mm})$ & 4 \\
T3 - Basalt dust B $(0.3 \mathrm{~mm})$ & 2 \\
T4 - Basalt dust B $(0.3 \mathrm{~mm})$ & 4 \\
T5 - Basalt dust C $(0.5 \mathrm{~mm})$ & 2 \\
T6 - Basalt dust C (0.5 mm) & 4 \\
T7 - Diatomaceous earth (INSECT0 $\left.{ }^{\circledR}\right)$ & 2 \\
T8 - Diatomaceous earth (INSECT0 & $\left.{ }^{\circledR}\right)$ \\
T9 - Control & 4 \\
\hline
\end{tabular}

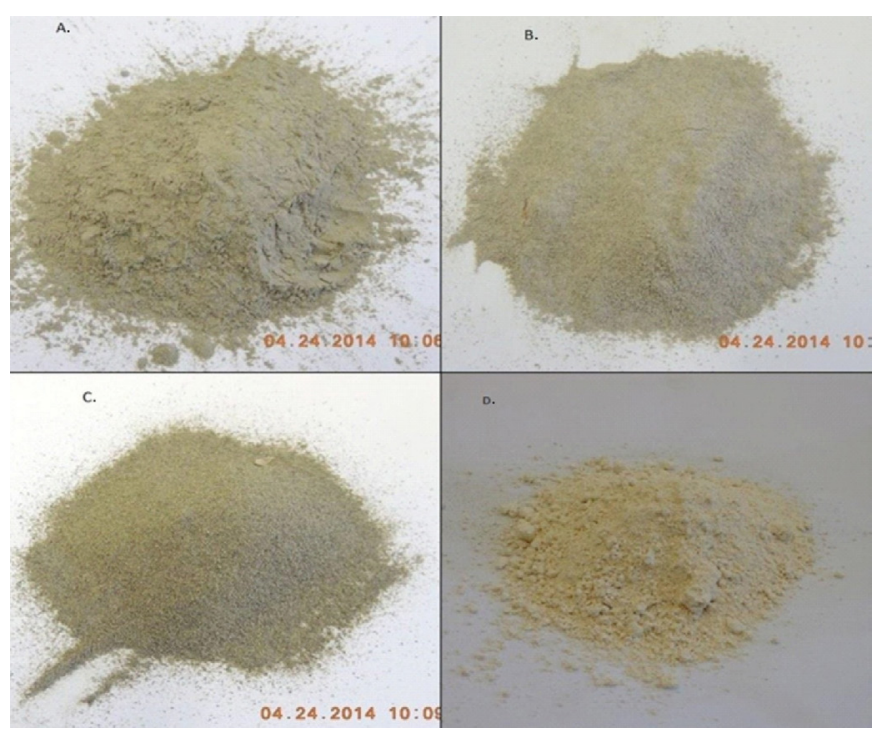

Figure 1. Basalt dusts (A, B and C) with granulometry of $0.1,0.3$ and $0.5 \mathrm{~mm}$, from the municipality of União da Vitória-PR provided by the company Ekosolos Indústria Remineradora de Solos Ltda., and commercial diatomaceous earth (D) (INSECTO ${ }^{\circ}$ ) provided by the company Bernardo Química 
Table 2. Total chemical analysis of basalt dusts with granulometry A $(0.1 \mathrm{~mm}), \mathrm{B}(0.3 \mathrm{~mm})$ and $\mathrm{C}(0.5 \mathrm{~mm})$ from the municipality of União da Vitória-PR used in the control of $S$. zeamais

\begin{tabular}{|c|c|c|c|c|c|c|c|c|c|c|c|c|}
\hline & $\mathrm{SiO}_{2}$ & $\mathrm{AL}_{2} \mathrm{O}_{3}$ & $\mathrm{TiO}_{2}$ & $\mathrm{Fe}_{2} \mathrm{O}_{3}$ & $\mathrm{CaO}$ & $\mathrm{MgO}$ & $\mathrm{K}_{2} \mathrm{O}$ & $\mathrm{Na}_{2} \mathrm{O}$ & $\mathrm{MnO}$ & $\mathrm{P}_{2} \mathrm{O}_{5}$ & p.f & Sum \\
\hline & \multicolumn{12}{|c|}{ (\%) } \\
\hline A & 51.13 & 13.99 & 1.21 & 13.48 & $10.79>\mathrm{UL}$ & 6.7 & 0.51 & 2.1 & 0.19 & 0.12 & 0.31 & 100.54 \\
\hline \multirow[t]{3}{*}{$B$ and $C$} & 65.46 & 12.41 & $1.05>U L$ & 7.04>UL & 3.28 & 1.56 & 3.37 & 4.01 & $0.13>L$ & $0.30>U L$ & 1.35 & 99.97 \\
\hline & $\mathrm{Sr}$ & $\mathrm{Zr}$ & $\mathrm{Nb}$ & $Y$ & $\mathbf{R b}$ & $\mathrm{Ba}$ & $\mathrm{Cu}$ & $\mathrm{Zn}$ & V & $\mathrm{Cr}$ & La & $\mathrm{Ni}$ \\
\hline & \multicolumn{12}{|c|}{$(p p m)$} \\
\hline A & 206 & 103 & 9 & 15 & 13 & 48 & 181 & 92 & 139 & 180 & 22 & 89 \\
\hline$B$ and $C$ & 192 & 174 & 28 & 52 & 173 & 701 & 150 & 101 & 114 & 21 & 52 & 52 \\
\hline
\end{tabular}

Source: FABIO, EIRS- Ltda. EIRS- Ekosolos Indústria Remineradora de Solos Ltda

treatment and replicate. The efficiency of control (EC, \%) was obtained using the equation of Abbott (1925):

$$
\mathrm{EC}=\frac{\mathrm{T}-\mathrm{Tr}}{\mathrm{T}} \times 100
$$

where:

$\mathrm{T}$ - number of live insects in the control; and

$\operatorname{Tr}$ - number of live insects in the treatment.

The data of live insects were subjected to analysis of variance and the means were transformed to $\sqrt{\mathrm{x}}+0.5$ and grouped by Tukey test at 0.05 probability level, using the program SAS (SAS Institute Inc., 2000).

\section{Results AND Discussion}

Through the analysis of variance, the chemical composition of the basalt dusts used in the study evidenced that silicon dioxide was the major component of the samples, with contents of $51.13 \%$ in treatment $A$ and $65.46 \%$ in B and C, followed by other constituents with lower percentages (Table 2). All the treatments with basalt dusts and diatomaceous earth differed from the control (without application) after 21 days of exposure (Table 3).

According to the results, the treatments with diatomaceous earth showed the highest efficiency, compared with the others, with value of $100 \%$ in the control of S. zeamais at both doses from 9 DAT on (Table 4).

For the three types of basalt dust, the evaluations also showed a satisfactory control in comparison to the control treatment, increasing the efficiency to $90 \%$, at 29 DAT. In general, the mortality was more pronounced 29 days after treatment, confirming that it increases with the increment in the time of exposure.

At 9 DAT, the mean number of live insects between both doses for the basalt dust A and B did not differ significantly, despite the significant difference between these treatments and the diatomaceous earth. On the other hand, at 29 DAT the treatments with basalt dust of different granulometries

Table 3. Mean values of live insects of Sitophilus zeamais, evaluated as a function of tie of exposure and different doses of basalt dust with granulometry $(0.1 \mathrm{~mm}), \mathrm{B}(0.3 \mathrm{~mm})$ and $\mathrm{C}(0.5 \mathrm{~mm})$ and diatomaceous earth under laboratory conditions during 29 days

\begin{tabular}{lcccccccc}
\hline \multirow{2}{*}{ Treatments } & Dose & \multicolumn{7}{c}{ Days after treatment (DAT) } \\
\cline { 3 - 9 } & $\left.\mathbf{( k g ~ t}^{-1}\right)$ & $\mathbf{5}$ & $\mathbf{9}$ & $\mathbf{1 3}$ & $\mathbf{1 7}$ & $\mathbf{2 1}$ & $\mathbf{2 5}$ & $\mathbf{2 9}$ \\
Basalt dust A & 2 & $7.25 \pm 0.4 \mathrm{ab}$ & $6.75 \pm 0.4 \mathrm{ab}$ & $6.25 \pm 3.3 \mathrm{ab}$ & $3.75 \pm 0.7 \mathrm{bc}$ & $1.50 \pm 0.6 \mathrm{bc}$ & $1.25 \pm 0.5 \mathrm{~b}$ & $0.75 \pm 0.2 \mathrm{~b}$ \\
Basalt dust A & 4 & $4.25 \pm 1.1 \mathrm{bc}$ & $3.50 \pm 1.4 \mathrm{bc}$ & $2.50 \pm 1.1 \mathrm{cb}$ & $2.25 \pm 1.1 \mathrm{bc}$ & $1.50 \pm 0.8 \mathrm{bc}$ & $1.25 \pm 0.8 \mathrm{~b}$ & $0.75 \pm 0.4 \mathrm{~b}$ \\
Basalt dust B & 2 & $6.75 \pm 0.4 \mathrm{abc}$ & $6.00 \pm 0.4 \mathrm{ab}$ & $4.75 \pm 0.5 \mathrm{bc}$ & $4.25 \pm 0.4 \mathrm{~b}$ & $3.50 \pm 0.6 \mathrm{bc}$ & $2.50 \pm 0.6 \mathrm{~b}$ & $1.25 \pm 0.4 \mathrm{~b}$ \\
Basalt dust B & 4 & $8.50 \pm 1.4 \mathrm{a}$ & $6.50 \pm 0.6 \mathrm{ab}$ & $4.25 \pm 0.7 \mathrm{bc}$ & $3.25 \pm 0.7 \mathrm{bc}$ & $2.25 \pm 0.7 \mathrm{bc}$ & $1.50 \pm 0.4 \mathrm{~b}$ & $0.75 \pm 0.4 \mathrm{~b}$ \\
Basalt dust C & 2 & $8.50 \pm 1.0 \mathrm{a}$ & $7.75 \pm 1.1 \mathrm{a}$ & $7.50 \pm 1.1 \mathrm{ab}$ & $5.75 \pm 1.5 \mathrm{ab}$ & $4.25 \pm 1.3 \mathrm{~b}$ & $3.25 \pm 1.4 \mathrm{~b}$ & $1.75 \pm 1.9 \mathrm{~b}$ \\
Basalt dust C & 4 & $3.50 \pm 0.8 \mathrm{~cd}$ & $3.25 \pm 0.9 \mathrm{bc}$ & $2.50 \pm 0.6 \mathrm{~cd}$ & $2.25 \pm 0.5 \mathrm{bc}$ & $2.00 \pm 0.7 \mathrm{bc}$ & $1.50 \pm 0.7 \mathrm{~b}$ & $0.75 \pm 0.7 \mathrm{~b}$ \\
Diatomaceous earth & 2 & $0.25 \pm 0.2 \mathrm{~d}$ & $0.00 \pm 0.0 \mathrm{C}$ & $0.00 \pm 0.0 \mathrm{~d}$ & $0.00 \pm 0.0 \mathrm{c}$ & $0.00 \pm 0.0 \mathrm{c}$ & $0.00 \pm 0.0 \mathrm{~b}$ & $0.00 \pm 0.0 \mathrm{~b}$ \\
Diatomaceous earth & 4 & $0.50 \pm 0.3 \mathrm{~d}$ & $0.00 \pm 0.0 \mathrm{C}$ & $0.00 \pm 0.0 \mathrm{~d}$ & $0.00 \pm 0.0 \mathrm{c}$ & $0.00 \pm 0.0 \mathrm{C}$ & $0.00 \pm 0.0 \mathrm{~b}$ & $0.00 \pm 0.0 \mathrm{~b}$ \\
Control & - & $10.0 \mathrm{a}$ & $10.0 \mathrm{a}$ & $10.00 \mathrm{a}$ & $10.00 \mathrm{a}$ & $10.00 \mathrm{a}$ & $10.00 \mathrm{a}$ & $10.00 \mathrm{a}$ \\
CV (\%) & & 8.08 & 4.74 & 3.86 & 4.82 & 5.34 & 6.67 & 2.36 \\
\hline
\end{tabular}

$\mathrm{CV}$ - Coefficient of variation; Means followed by the same letter in the columns do not differ by Tukey test at 0.05 probability level

Table 4. Efficiency of control (EC\%) of three types of basalt dust, with granulometry A $(0.1 \mathrm{~mm}), \mathrm{B}(0.3 \mathrm{~mm})$ and C $(0.5$ $\mathrm{mm}$ ), and diatomaceous earth on adults of $S$. zeamais, evaluated as a function of time of exposure under laboratory conditions during 29 days

\begin{tabular}{|c|c|c|c|c|c|c|c|c|}
\hline \multirow{2}{*}{ Treatment } & \multirow{2}{*}{$\begin{array}{c}\text { Dose } \\
\left(\mathrm{kg} \mathrm{t}^{-1}\right)\end{array}$} & \multicolumn{7}{|c|}{ Time of exposure } \\
\hline & & 5 & 9 & 13 & 17 & 21 & 25 & 29 \\
\hline Basalt dust $\mathrm{A}$ & 2 & 25.64 & 28.95 & 34.21 & 60.53 & 84.21 & 86.49 & 91.89 \\
\hline Basalt dust A & 4 & 56.41 & 63.16 & 73.68 & 76.32 & 84.21 & 86.49 & 91.89 \\
\hline Basalt dust $B$ & 2 & 30.77 & 36.84 & 50.00 & 55.26 & 60.53 & 75.68 & 86.49 \\
\hline Basalt dust $B$ & 4 & 12.82 & 31.58 & 55.26 & 65.79 & 76.32 & 83.78 & 91.89 \\
\hline Basalt dust C & 2 & 12.82 & 18.42 & 21.05 & 39.47 & 55.26 & 64.86 & 81.08 \\
\hline Basalt dust C & 4 & 64.10 & 65.75 & 73.68 & 76.32 & 78.95 & 83.78 & 91.89 \\
\hline Diatomaceous earth & 2 & 97.44 & 100 & 100 & 100 & 100 & 100 & 100 \\
\hline Diatomaceous earth & 4 & 94.87 & 100 & 100 & 100 & 100 & 100 & 100 \\
\hline
\end{tabular}


and the treatments with diatomaceous earth did not differ significantly.

Pinto Júnior (2008), studying the mortality of Sitophilus oryzae (Linnaeus, 1763) exposed to different doses of diatomaceous earth, observed effect between the dose and the period of exposure, i.e., longer periods of exposure at the highest doses promoted better control of the insects, which was confirmed in the present study. The data in Table 3 show that, at $5 \mathrm{DAT}$, there were significant differences between the doses of the basalt dust $C$ and the same occurred at 9, 13 and 17 DAT.

In general, the treatments based on basalt dust and diatomaceous earth at both doses drastically reduced the mean number of live insects of $S$. zeamais in relation to the control, for all times of exposure. With the increment in days after treatment, the survival was approximately zero.

In a study on the insecticide activity of two types of diatomaceous earth on Rhyzopertha dominica (Fabricius, 1972) and S. oryzae, Baldassari \& Martini (2014) observed that diatomaceous earth at all times of exposure differed significantly from the control and caused mortality higher than $70 \%$. After 14 days of exposure, insect mortality was than $88 \%$ in all the treatments and no difference between the treatments with diatomaceous earth, corroborating the results obtained in the present study (Table 4).

The results obtained in the present study are similar to those reported by Silva et al. (2007), who studied the effects of rock dusts and shale by products on the control of $S$. zeamais in stored corn grains and observed that the number of live insects in treated corns reached zero from 30 DAT on.

The diatomaceous earth at the dose of $2 \mathrm{~kg} \mathrm{t}^{-1}$ showed good efficiency of control. In a similar study, Morais et al. (2009) evaluated the effect of diatomaceous earth as an alternative control of Oryzaephilus surinamensis (Linnaeus, 1758) in stored corn and observed that the dose of $1.5 \mathrm{~kg} \mathrm{t}^{-1}$ was sufficient to kill all the insects, confirming its efficiency.

Mewis \& Ulrichs (2001) observed that at low doses of diatomaceous earth ( 0.2 and $\left.4 \mathrm{~g} \mathrm{~cm}^{-2}\right)$, a longer time of exposure is necessary to reach a satisfactory result in the control of Tenebrio molitor (Linnaeus, 1758), Sitophilus granarius (Linnaeus, 1875) and Plodia interpunctella (Hubner, 1813). Also according to these authors, the increase in the time of exposure is related to the mode of action of inert dusts on the insects.

Inert dusts efficiency can be influenced by many factors, such as grain moisture and temperature. The corn grains used in the study showed moisture of $12 \%$ and temperature $25 \pm$ $3^{\circ} \mathrm{C}$, which contributed to the efficiency of the dusts. Lorini (1998) observed that the efficiency of inert dusts depends on whether the grains are dry or not, with moisture lower than $13 \%$. In addition, Antunes et al. (2011) observed that corn grains with 14 and $16 \%$ of moisture showed higher percentage of damage caused by $S$. zeamais and Tribolium castaneum (Herbst, 1797), being more easily attacked by these species. Le Patourel (1986) studied the effect of moisture content on the efficiency of control of sorptive silica dust in four beetle species [S. granarius, T. castaneum, Cryptolestes pusillus (Schoenherr, 1817 ) and O. surinamensis] in wheat with different moisture contents. This author observed that the tolerance of these species to the silica dust treatment increases with the increment in moisture content, which obviously reinforces its sorptive character. The diatomaceous earth has higher effect of adherence to the epicuticle of the insect, in comparison to the basalt dust (Subramanyam; Roesli, 2000), and the mixture of inert dusts can intensify the insecticide effect, increasing the adherence to the insects.

One of the reasons for using diatomaceous earth in largescale storage is the fact that it is efficient at lower doses, which in this case also supports the use of basalt dusts, because both are efficient in the same volume of application. Considering the evaluated doses, diatomaceous earth and basalt dust did not show significant differences at 17, 21, 25 and 29 DAT; thus, the lowest dose $\left(2 \mathrm{~kg} \mathrm{t}^{-1}\right)$ can be used.

Since the insects have small bodies, with long appendices, they have large evaporation surfaces per unit volume, facilitating the loss of water (Ebeling, 1971). According to this author, the death occurs when the insects lose $30 \%$ of its total weight or $60 \%$ of the body water content. According to Subramanyam \& Roesli (2000), silica dioxide is able to break the wax layer of the epicuticle of insects. Thus, with the composition of the basalt dusts used in the present study, with $\mathrm{SiO}_{2}$ content of $65.46 \%$ (Table 2), it is expected that they adsorb the molecules of the wax layer on the insect surface (Figure 2), leading to the break of the protective lipid layer and the consequent loss of liquid by the body, causing death.

On the other hand, in a similar study, Ribeiro et al. (2008) evaluated the efficiency of inert dusts in the control of $S$. zeamais until 21 days of exposure and observed that insect mortality was associated with a probable fago-deterrent action of the products or even resulted from the decrease in movement and activity in the mass of grains, caused by the adhesion of particles from the treatments to the body of the insects.

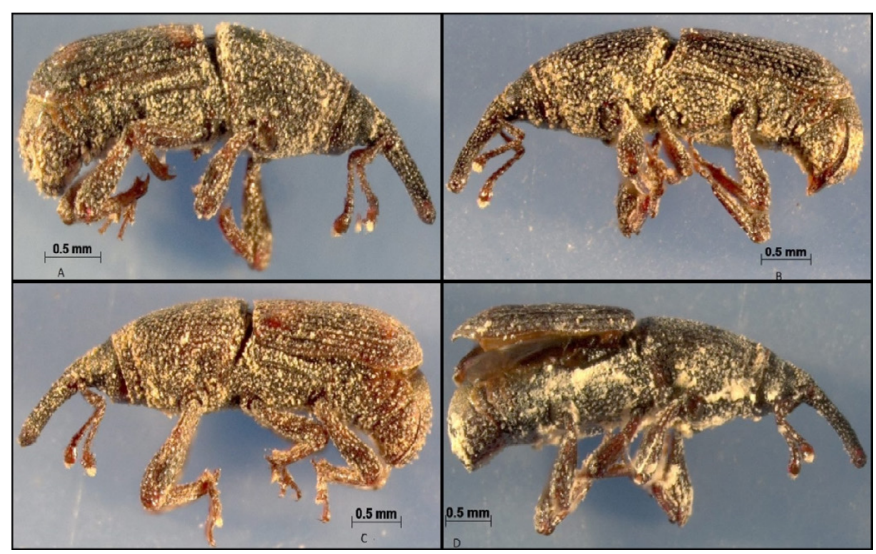

Images made with a Zeiss Discovery.V20 stereomicroscope equipped with a Zeiss AxioVision 4.8.2 system

Figure 2. Effect of inert dusts mixed with corn grains (A - basalt dust granulometry of $0.1 \mathrm{~mm}, \mathrm{~B}$ - basalt dust granulometry of $0.3 \mathrm{~mm}, \mathrm{C}$ - basalt dust granulometry of 0.5 $\mathrm{mm}, \mathrm{D}$ - diatomaceous earth) on the cuticle of $S$. zeamais

\section{Conclusions}

1. S. zeamais mortality increases with the increment in the time of exposure to basalt dusts and diatomaceous earth. This effect was faster with the diatomaceous earth, reaching $100 \%$ of mortality on the fifth day of exposure. 
2. The three types of basalt dusts, with granulometries of $0.1,0.3$ and $0.5 \mathrm{~mm}$, and at doses of 2 and $4 \mathrm{~kg} \mathrm{t}^{-1}$, reached efficiency of control of S. zeamais above $80 \%$.

\section{Literature Cited}

Abbott, W. S. A method of computing the effectiveness of an insecticide. Journal of Economic Entomology, v.18, p.265-267, 1925. http://dx.doi.org/10.1093/jee/18.2.265a

Almeida, F. de A. C.; Goldfarb, A. C.; Gouveia, J. P. G. de. Avaliação de extratos vegetais e métodos de aplicação no controle de Sitophilus spp. Revista Brasileira de Produtos Agroindustriais, v.1, p.13-20, 1999. http://dx.doi.org/10.15871/1517-8595/rbpa.v1n1p13-20

Antunes, L. E. G.; Ferrari Filho, E. F.; Gottardi, R.; Sant'Ana, J.; Dionello, R; G. Avaliação do uso de terra de diatomácea contra infestação de grãos armazenados. Revista Brasileira de Ciências Agrárias, v.6, p.662-669, 2011. http://dx.doi.org/10.5039/agraria. v6i4a1486

Antunes, L. E. G.; Ferrari Filho, E. F.; Gottardi, R.; Sant'Ana, J.; Dionello, R. G. Efeito da dose e exposição à terra de diatomácea de diferentes insetos em milho armazenado. Arquivo do Instituto Biológico, v.80, p.169-176, 2013. http://dx.doi.org/10.1590/S180816572013000200005

Arthur, F. H. Grain protectant chemical: present status and future trends. In: Proceedings... International Working Conference on Stored-Product Protection, 6., v.2, p.719-721, 1994.

Baldassari, N.; Martini, A. The efficacy of two diatomaceous earths on the mortality of Rhyzopertha dominica and Sitophilus oryzae. Bulletin of Insectology, v.67, p.51-55, 2014.

Ceruti, F. C.; Lazzari, S. M. N. Combination of diatomaceous earth and powder deltamethrin for insect control in stored corn. Revista Brasileira de Entomologia, v.49, p.580-583, 2005. http://dx.doi. org/10.1590/S0085-56262005000400020

Ebeling, W. Sorptive dusts for pest control. Annual Review of Entomology, v.16, p.123-158, 1971. http://dx.doi.org/10.1146/ annurev.en.16.010171.001011

Faroni, L. R. D. A. Manejo das pragas dos grãos armazenados e sua influência na qualidade do produto final. Revista Brasileira de Armazenamento, v.17, p.36-43, 1992.
Gallo, D.; Nakano, O.; Silveira Neto, S.; Baptista, G. C.; Berti Filho, E.; Parra, J. R. P.; Zucchi, R. A.; Alves, S. B.; Vendramim, J. D.; Marchini, L. C.; Lopes, J. R. S.; Omoto, S. Entomologia agrícola. Piracicaba: FEALQ, 2002. 920p.

Le Patourel, G. N. J. The effect of grain moisture content on the toxicity of a sorptive silica dust to four species of grain beetle. Journal of Stored Products Research, v.22, p.63-69, 1986. http://dx.doi. org/10.1016/0022-474X(86)90020-2

Lorini, I. Controle integrado de pragas de grãos armazenados. Passo Fundo: EMBRAPA-CNPq, 1998. 52p.

Mewis, L.; Ulrichs, C. Action of amorphous diatomaceous earth against different stages of the stored product pest Tenebrio molitor, Sitophilus granarius and Plodia interpunctella. Journal of Stored Products Research, v.37, p.153-164, 2001. http://dx.doi. org/10.1016/S0022-474X(00)00016-3

Morais, M. B.; Crespo, F. L. S.; Dos Santos, V. B.; Ferraz, F. B.; Silva, D. A. Uso de terra diatomácea como controle alternativo do Oryzaephilus surinamensis em milho armazenado. Diversa, v.2, p.1-9, 2009.

Pinto Júnior, A. R. Eficiência de terra de diatomáceas no controle de algumas pragas de milho armazenado a granel. Revista da FZVA, v.15, p.61-70. 2008.

Porto, M. F.; Soares, W. L. Modelo de desenvolvimento, agrotóxicos e saúde: um panorama da realidade agrícola brasileira e proposta para uma agenda de pesquisa inovadora. Revista Brasileira de Saúde Ocupacional, v.37, p.17-50, 2012. http://dx.doi.org/10.1590/ S0303-76572012000100004

Ribeiro, L. P.; Costa, E. C.; Bidinoto, V. M. Avaliação da eficácia de pós inertes no controle de Sitophilus zeamais Mots. (Coleoptera; Curculionidae). Revista da FZVA, v.15, p.19-27, 2008.

SAS Institute Inc. SYSTEM $2000^{\circ}$ Software: Product support manual, Version 1, First Edition, Cary: SAS Institute Inc., 2000.

Silva, P. H.; Trivelin, P. C. C. O.; Guirado, N.; Ambrosano, E. J.; Mendes, P. C. D.; Rossi, F.; Arevalo, R. A. Controle alternativo de Sitophilus zeamais Mots. (Coleoptera: Curculionidae) em grãos de milho. Revista Brasileira de Agroecologia, v.2, p.902-905, 2007.

Subramanyam, B.; Roesli, R. Inert dusts. In: Subramanyam, B.; Hagstrum, D. W. (ed.), Alternatives to pesticides in stored-product IPM. Boston: Kluwer Academic Publishers, 2000. p.321-380. http://dx.doi.org/10.1007/978-1-4615-4353-4_12 